\title{
A survey on the evolution of the Chinese cadastral system
}

\author{
Chenjing Jiao ${ }^{a *}$, Lorenz Hurnia \\ ${ }^{a}$ Institute of Cartography and Geoinformation, ETH Zürich, Switzerland, cjiao@ethz.ch \\ * Corresponding Author
}

\begin{abstract}
Cadastral system plays a pivotal role in land administration, which has attracted notable attention from researchers and policy-makers worldwide. Despite China being the most populous country throughout the world, its cadastral system is rarely studied. This paper conducts a comprehensive survey on the evolution of the Chinese cadastral system by elaborating the historical and contemporary Chinese cadastre. Specifically, contemporary Chinese cadastre is articulated from the aspects including content and purpose, legal basis, organization, and technical approaches, and compared with Swiss and Hong Kong cadastre. It is concluded that the Chinese cadastre evolved in a different way from that of the western countries due to China's unique historical and economic background. This study sheds light on systematically understanding the development of the Chinese cadastre and further refining contemporary Chinese cadastral system.
\end{abstract}

Keywords: cadastral system; cadastral map; the evolution of cadastre; comparison between cadastral systems; land administration

\section{Introduction}

The fundamental role of cadastral systems in land administration is well acknowledged, which leads to increasing interest of researchers worldwide (Ting and Williamson, 1999, Rajabifard et al., 2007, Lin et al., 2015). The Chinese cadastral system has been gradually established during the last decades, which plays an increasingly important role in land administration. The emergence of various new techniques accelerates cadastral development, and facilitates its application in different areas. Due to unique historic, economic, and cultural reasons, the Chinese cadastre evolved and develops in a different way from the typical cadastral evolution path.

However, little attention is given to the study on the Chinese cadastral system itself (Lin et al., 2015). Specifically, most of the studies focus either on the application of new techniques in cadastral survey (Liu, 2019, Song, 2019), or on cadastral management (Jiang, 2008, Feng, 2012, Lin et al., 2015). Some other studies summarize the history and evolution of the Chinese cadastre (Fan, 2007), but either lack necessary discussion on how the historic evolution and social factors affect the contemporary cadastre, or focus on only a short period of history (Liu, 2010). Furthermore, few studies give a comprehensive comparison between the Chinese and the western cadastre.

In this paper, we present the evolution of the Chinese cadastre against its historic context, understand the contemporary Chinese cadastre from different aspects, and compare it with the Swiss cadastre. The paper is structured as follows: Section 2 gives a country profile for a general understanding of China. Section 3 elaborates the Chinese cadastre in a historic perspective, followed by section 4 , which provides insight into the contemporary cadastre from aspects including content and purpose, legal basis, organization, technical approaches, and comparison with the Swiss cadastre. Section 5 summarizes the paper and provides a discussion and a conclusion.

\section{Country profile}

China, officially the People's Republic of China (PRC), is situated in East Asia, covering approximately 9.6 million $\mathrm{km} 2$. China is the world's most populous country, with a population of over 1.39 billion in the year 2017 (Yearbook, 2017). Its landscapes vary significantly across its vast territory, ranging from mountain ranges and plateaus in the west to the densely populated plains in the east, from broad grassland in the north, the extensive plain in central China, to hills and low mountain ranges in the south (Feng and Sun, 2011).

China emerged as one of the world's earliest civilizations, with a long history of 5,000 years. For millennia, China was under the rule of hereditary monarchies, known as dynasties, beginning with the Xia Dynasty (around 2,000 $\mathrm{BC}$ ). Feudal dynastic rule ended in 1912, when the Republic of China (1912-1949) replaced the Qing Dynasty (1644-1911), the last imperial dynasty in China. The People's Republic of China was established in 1949. It is one of the world's few remaining socialist states with a unique political economy (Lin et al., 2015).

In Qin Dynasty (221-207 B.C.), private land ownership had been determined in legal form. Land tax had always been the main source of national finance, with the taxation object evolving from resident to land and property. The land policy of the government of the Republic of China (19121949) aimed at two principles, i.e. equalizing land rights and controlling/moderating capital, advocating the cultivator owning his land (Liu, 2010). The socialist transformation movement taking place in the 1950s after the establishment of the PRC turned private land ownership into national or collective land ownership. Rural land is owned in a collective way, which is contracted by family units, while urban land is usually owned nationally. Property owners have a 70-year right to use the land in urban areas. 


\section{History of the Chinese cadastre}

China has a long history as generally recognized. Historical dynasties of China developed many policies, strategies, and measures concerning land management, mainly aiming at developing economy and implementing governance. Cadastral management is valued by each of the dynasties, with the history of the cadastre in China traced back to as early as 2100 B.C. (Lin et al., 2015).

Before the establishment of the Qin Dynasty (221-207 BC), land was owned by the King or by a clan. At that time, cadastral management corresponding to arable land has been as an important part of governance with the development of ancient agriculture. The authorities implemented surveying land boundaries and drawing land maps according to legal formalities. The land across the country was classified into 3 classes, with each class sorted into 3 levels. Land tax was imposed according to the land level (Yu, 2003). Besides, land transfer emerged in the form of rewarding, trading, etc. Special officers were responsible for administrating the contract signing procedure. The contract and the land transfer process were recorded on tripod or bronze (Fan, 2007).

As the first imperial and absolute monarchy dynasty, the Qin Dynasty unified China in 221 BC. Private land ownership was recognized and protected by law. Land tax was imposed according to an overall land register result implemented by the authorities throughout the country. There are three basic types of land ownership in the feudal times, namely self-cultivator, landlord, and state land ownership. Throughout later dynasties several national large-scale land / property investigations and census have been carried out. The government set special official positions or a department responsible for land registration (Fan, 2007). The Chinese cadastre developed with laws and regulations being gradually perfected, cadastral survey technologies gradually improved, and the format of land register gradually unified from various local forms.

Land commercialization emerged and rose with economic development. In Tang Dynasty (618 to 907), land transfer was required to be officially registered. Private contracts weren't allowed. Census and land investigations were carried out every few years by the government, with a cadastre book being compiled accordingly (Fan, 2007). In later historic time, the content and format of the land transfer contract gradually specialized and standardized, and land transfer tax was imposed.

In the Song Dynasty (960-1279), land certificates (named "wen contracts") emerged as verifications for officially recognized land ownership. A kind of guarantee map was added to the land parcel map. Each land parcel, and its surrounding hills, water bodies and roads or streets must be connected and corresponded from each direction in the guarantee map, which was further combined into an atlas. The first emperor of the Ming Dynasty (1368 to 1644) ordered to thoroughly survey and investigate the land, with the results drawn to maps, and maps were further compiled into an atlas. The atlas also includes attribute information like land level as shown in Figure. 1 (Fan, 2007).

In the Qing Dynasty (1644 to 1911) the government was not only able to precisely conduct land survey and land statistics, but also to update the cadastre according to the

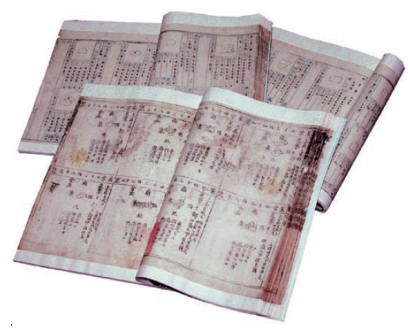

Figure 1. Land parcel atlas in Ming Dynasty.

dynamics in seashore areas. Cadastral archives were highly valued, and land certificate was issued officially. Land transfer further developed with the booming of commodity economy. Western land survey methods were introduced (Fan, 2007). But large-scale land survey project required a huge amount of money and technical survey capabilities. With the national power declining in the late Qing Dynasty, local land tax was estimated based on the outdated cadastre. With time passing by, the cadastral archives can hardly be reliable at the beginning of the Republic of China (1912-1949), either due to the destruction of some of them during the war in the last years of the Qing Dynasty, or passed to individuals (Liu, 2010).

The government of the Republic of China realized the necessity of revising the cadastre, as it would greatly benefit the national finance. Land survey was one of the key tasks included in revising and updating cadastre. However, the national finance at that time could hardly support a largescale land survey, resulting in a bad performance of the so-called "cadastre checking up". Besides, the beginning of the war in 1937 disarrayed many national policies and measures (Liu, 2010).

Overall, land tax has always been the main source of national finance throughout the long historic period. Accordingly, the cadastre or land register serves as a fiscal purpose, and verification proof for land litigation. The function of the Chinese cadastre as a tool for supporting land transfer and land market was relatively weak, compared with the cadastral development during the same historic period in western countries. This can be attributed to that China has long been a huge agricultural country, with most people tied to land in a physical way. Furthermore, land transfer and land market rose in the background of the emergence of capital, but the development of the capitalism and the bourgeoisie was weak in Chinese history, resulting in insufficient requirements for the cadastre as a tool for supporting the land market. The development of the Chinese cadastre couldn't rely on a long stable social and economic environment, especially in the second half of 1800s and the first half of 1900s. Wars that broke out due to regime changes disrupted social order, and destroyed some cadastral documents. The society gradually tends to be stable after the establishment of PRC in 1949.

Public land ownership is established in the commune movement taking place in 1950s (Luo, 2009), meaning land ownership is separated from land use right. This event affected the cadastral process in the long run. The Outline for Making Land Inventory for Agricultural Tax was issued in 1951, which resulted in the first large-scale cadastral inventory including an inventory of the amount of land, division of categories of land, assessment of land levels, etc. 
The cadastre worked as a kind of fiscal cadastre (Jiang, 2008). Cadastral work was done under the land administration department with an administrative function. No specific cadastral organization was formed till then. However, it cannot be denied that the cadastral practices such as the issue of land use certificates and the first large-scale cadastral inventory paved the way for the later establishment of the Chinese cadastral system (Lin et al., 2015).

\section{Contemporary Chinese cadastre}

$\mathrm{n}$ this section, five aspects from the contemporary Chinese cadastre are presented, namely content and purpose, legal basis, organization, technical approaches, comparison with the Swiss cadastre.

\subsection{Content and purpose}

As the core or basis of a land administration system, a cadastre is a parcel-based updated land information system containing records of basic information, like parcel location, area and use, and land interests, such as rights, restrictions and responsibilities. The cadastre, managed by official institutions, facilitates the government to grasp the current land status with additional information, including land tenure, ownership, easements, and mortgages, etc. The Chinese cadastral system is established based on title registration. It involves many aspects such as land investigation, land use inventory, land classification and land appraisement, land registration, land statistics, cadastral management, cadastral management information system, etc. (Cadastral-Template, 2003).

A land owner or user is required to register the land at the local land management department. Figure.2 (Lin et al., 2015) is a sample of a land registry application form, which includes the basic information of land and land ownership, such as land location, area, land use type, parcel number, etc. There are two types of land registration in China, original registry and variation registry. The variation registration is conducted in case of land and land right transfer, change, writing-off, etc. after the original registration.

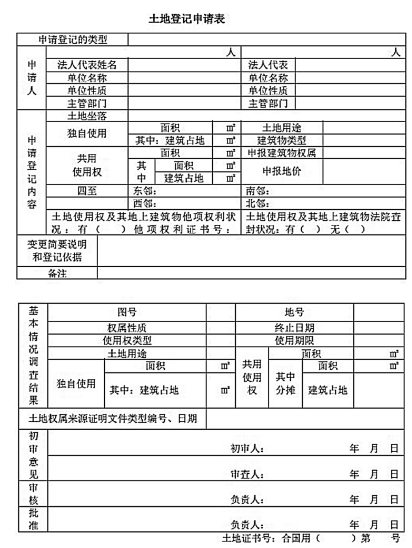

Figure 2. A sample of land registry application form.

The cadastral map is often made with the cadastral information system backed by the cadastral database, which includes data of parcel, registers, owner, building, road, and topographic features. A cadastral map consists of different layers, like the parcel distribution layer, the parcel layer and the land classification layer, etc. The parcel distribution map is the fundamental information for the cadastral management, which includes the boundaries of parcels, topographic features, parcel number as identifier, owner, etc. Figure. 3 (Cadastral-Template, 2003) shows an example of the parcel distribution map. A parcel map must be generated when a land certificate is issued to the owner or user of the parcel. Generally, a parcel map consists of parcel position, surroundings, boundary point coordinates, and attributes such as the owner, area and land use type(Cadastral-Template, 2003). A parcel map example is shown in Figure. 4 (Cadastral-Template, 2003).

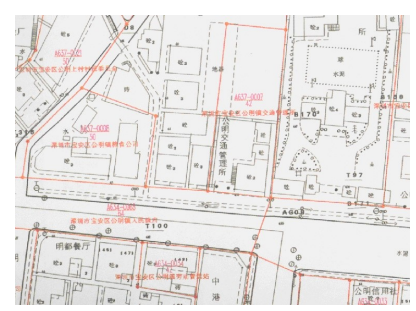

Figure 3. An example of a parcel distribution map in Shenzhen city, Guangdong Province.

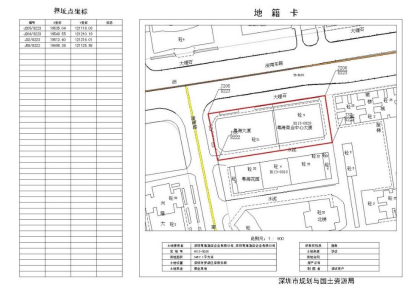

Figure 4. A parcel map in Shenzhen city, Guangdong Province.

The Spatial Data Infrastructure (SDI) has been planned and developed for several years in China. The topographic map of digital line graph (DLG) is established nationwide. Digital cadastral data is produced and applied based on topographic databases at the scales of 1:500, 1:1000 and 1:2000 (Cadastral-Template, 2003). The Chinese cadastral management information system has been developed for several years. It integrates modern technology with cadastral management operation model, aiming at providing a rapid and accurate cadastral service for society and the government. Cadastral information has become an essential support of the national land resource information.

In the long historic period, the cadastre was mainly used for fiscal purposes, which gradually evolved into a juridical cadastre after the foundation of the PRC. Land market grew and gradually matured only after the economic reform implemented in late 1970s. A multi-purpose cadastre and a land information system have gradually been established and put into use. The main purpose and applications of such systems, however, are still limited in the land administration domain (Cadastral-Template, 2003). The government or other official departments are the primary users of the systems.

\subsection{Legal basis}

The Chinese economic reform started in 1978, and the strategy of reform and opening-up was determined, aiming at shifting the national focus to economic development. The household responsibility system was adopted in rural areas, which resulted in a profound change in land tenure. 
Rural land use rights were decentralized to the individual farm households (Cheng et al., 2006).

The general and detailed land survey in China was in full swing which was followed by land registration and land statistics. In 1984, the State Council forwarded Notice on the Further Survey of Land Resources, resulting in a nationwide detailed survey on land use conducted for the first time (Jiang, 2008). The cadastre was developed to be a juridical cadastre (Lin et al., 2015).

Establishing and improving the cadastral management system was first proposed in 1986 in the Notice on Strengthening Land Management to Stop the Unlawful Appropriation of Farmland by State Council (Lin et al., 2006). In the same year, the Land Administration Law of the People's Republic of China was promulgated, which specifically defined the land registration system, the land survey system, and the land statistics systems. The cadastral work was promoted to the legal level for the first time (Feng, 2012). Subsequently, multiple rules and regulations on cadastral work were issued, such as Regulations on the Cadastral Survey in Urban Areas in 1989, Technical Regulations on Inventory of Land Use Survey on Prefecture Level in 1993 and Rules on Land Registration in 1995 (Lin et al., 2015). The new Land Administration Law of 1999 clearly defined the establishment of a national land management information system and stated to conduct dynamic monitor on land use (Wang, 2001).

The first Chinese national plan for the cadastre - Outline for Cadastral Development in the Tenth Five-Year (2001-2005) was issued in 2001, which summarized cadastral work done from 1996 to 2000 and deployed the cadastral work from 2001 to 2005 . The cadastre was promoted to be at a national level for the first time in legislation. Furthermore, the second national cadastral plan - Outline for Cadastral Development in the Eleventh Five-Year (2006-2010), was issued in 2006. These two five-year plans make a sound foundation for cadastral work in China (Lin et al., 2015).

The legislation on the cadastral system then gets more and more formalized. In 2006, the Notice on the Second National Land Survey was announced which decided to launch the second national detailed land survey. The National Standard of Land Use Classification (GB/T21010-2007) was issued in 2007. The Cadastral Database Standard was released, which promoted the unification of the cadastre in urban and rural areas. The Property Law was promulgated to assure the implementation of the unified registration system for real estate, which facilitates house ownership, especially apartment ownership (Lin et al., 2015).

\subsection{Organization}

With cadastral management playing an increasingly important role in China, a five-level organization structure of the national cadastral management agencies gradually formed in 2000s, following the establishment of the Cadastral Management Department belonging to the Ministry of Land and Resources in late 1990s, and the cadastral office as a functional part of the Ministry of Land and Resources in late 1980s. Specifically, the five-level structure includes the Cadastral Management Department in the Ministry of Land and Resources, the Cadastral Management Bureau in the Provincial Department of Land and
Resources, the Cadastral Management Office in Municipal Bureau of Land and Resources, the Cadastral Management Division in County Level Bureau of Land and Resources, and the Township Level Office of Land and Resources (Luo, 2009).

Cadastral management agencies in the national and provincial levels focus primarily on macroeconomic policy and guidance. Besides, the State Bureau of Surveying and Mapping of China takes charge of the national basic survey, and the overall administration of the survey. It also formulates the plans and technical standards for the cadastral survey, manages the verification of cadastral survey qualifications, and certifies the survey results. Cadastral management agencies on the municipal level and county level undertake the daily work of the cadastral survey and land registration. Overall, the organization structure is characterized by the subordinate relation between the land administration department and the cadastral management department (Lin et al., 2015).

The private sector is also involved in the cadastral survey besides the official institutions. There are about 6,000 surveying and mapping agencies or companies in China, which are qualified in four grades. These professional agencies or enterprises must register in local administrative offices of survey (Cadastral-Template, 2003).

\subsection{Technical approaches}

Coordinate systems employed in the Chinese cadastral survey can either be a locally independent system or a national system. Commonly used map scales include 1:500, 1:1000, and 1:2000. The precision required for parcel points can be $5 \mathrm{~cm}, 10 \mathrm{~cm}$, or $25 \mathrm{~cm}$ (Shen and Cao, 1993). Approaches used in the cadastre survey generally include automatic or semi-automatic methods, the plane-table method, compilation, aero photographic and remote sensing technology, as well as the Lidar method.

1. Automatic or semi-automatic methods. In an automatic way, total stations are used to collect survey data in the field. Then the data is transferred and processed, thereby outputting a cadastral map at a required scale. Due to the high expense of the equipment used for the automatic survey, however, a semiautomatic method is more commonly used, which adopts an ordinary theodolite together with a pocket computer (Shen and Cao, 1993).

2. Compilation. Since large-scale topographic maps are easily available, features required on the cadastral map are compiled based on the existing maps, except for coordinates of parcel points, which are measured directly in field. This method is both time- and moneysaving (Shen and Cao, 1993).

3. Aerophotographic and remote sensing method. In conventional photogrammetry, the image data are obtained with a high-resolution aerial camera carried by airplane. Then, point coordinates and elevation are computed through aerotriangulation. Field check and mapping is necessary to minimize the survey error. In recent years, the technique of unmanned aerial vehicle (UAV) oblique photogrammetry has been gradually maturing, which indicates its application feasibility in survey and mapping, especially in 1:500 cadastral survey. The UAV photogrammetry system consists of a UAV as a carrier, a digital camera to capture 
high resolution image, a GPS and an inertial navigation system for flight control, a land control system and a communication device. Oblique photogrammetry data processing software, like Bentley Context Capture center, can be used to conduct aerotriangulation and create 3D real-scene models, based on data processing for UAV oblique image, position and orientation system (POS) data, and image control points. The error is computed by comparing point coordinates measured by a total station with the coordinates of the corresponding points on the 3D model, thereby verifying the precision of the cadastral survey (Song, 2019). But the drawback lies in that the precision cannot be guaranteed in case of occlusion.

Remote sensing technology is mainly used for monitoring land dynamics. A digital orthophoto map (DOM) and the latest remote sensing image can serve as the base maps for cadastral survey. The points that need to be re-surveyed and updated can be detected and found according to the base map. Remote sensing technology has been fully used in the 2nd National Land Investigation of China.

4. Lidar. The applicability of Lidar (light detection and ranging) has been proved in 1:500 cadastral survey. The mobile Lidar system integrates GNSS, an Inertial Measurement Unit, a laser scanning system, a central control unit, and a digital camera. After processing the obtained image and point cloud data, cadastral mapping software is used to create cadastral map.

\subsection{Comparison with the Swiss Cadastre}

Cadastral systems differ in countries due to their specific historical, political, economic and cultural context (Lin et al., 2015). Here we make a comparison between the Swiss, Chinese mainland, and Hong Kong cadastres, from the perspectives of their cadastral principles, statistics, and education or training systems.

Both Switzerland and China mainland have a title registration cadastral system, while Hong Kong has a mixed system with both title and deeds registration. The registration of land ownership is compulsory by law in Switzerland, while it is optional in China mainland and Hong Kong. Switzerland has a systematic registration during the initial establishment of the cadastre, while China mainland has both systematic and sporadic registration. All properties have already been registered in Hong Kong (CadastralTemplate, 2003).

The urbanization rate of Switzerland is $75.00 \%$ in 2019 , while the indicator value is $58.52 \%$ in China mainland. Hong Kong has an urbanization rate of $97 \%$ (CadastralTemplate, 2003). Since the number of parcels differs greatly between Switzerland and China due to the huge difference in land area, here we compare the number of parcels per million people. In Switzerland, the number of parcels per million people is about 476,600, while in China it is about 205,400 (Cadastral-Template, 2003). In Hong Kong there are only 300,000 land parcels, but about 2 million strata or condominium units. If these strata unit titles were taken into account in this ratio, the number of parcels per million people in Hong Kong would be over 340,000 (Rajabifard et al., 2007). The number of registered strata units per million population in Switzerland is less than 23,700, while for China mainland it's 156,600, and 284,600 for Hong
Kong (Cadastral-Template, 2003). Switzerland has 100\% parcels legally registered and surveyed. For Hong Kong the indicator value is nearly $100 \%$. The value is unavailable for China mainland (Cadastral-Template, 2003).

The professional level is another important aspect for comparison, which indicates the professional extent of a nation's cadastral system and the maturation of the land market. The number of full-time equivalent professional land surveyors is 283 in Switzerland, 4,500 in China mainland, and 10 in Hong Kong, respectively (Cadastral-Template, 2003). It makes more sense to compare the indicator against per million people, which is 33.08 in Switzerland, 3.15 in China mainland, and 1.35 in Hong Kong. China has a very low professional surveyor ratio because land transfer is not as common as in western countries, which is a strong influence on the number of land transactions being carried out. The low professional value of Hong Kong probably results from the high level of strata units (Rajabifard et al., 2007). Switzerland has 490 full-time equivalent lawyers or solicitors, but the number of lawyers or solicitors remains unknown in China mainland. Hong Kong has 660 full-time equivalent lawyers or solicitors(CadastralTemplate, 2003). Accordingly, Switzerland has 57.27 fulltime equivalent lawyers or solicitors per million population, while Hong Kong has 89.29, indicating an unusually high ratio of over 66 lawyers to every surveyor, which results from the fact that legally qualified surveyors can also act as lawyers in some cases (Rajabifard et al., 2007).

The education or training system for cadastres strongly influences the professional level, and to some extent implies the future development of a country's cadastral system. Requirements for a professional surveyor tend to be comprehensive in Switzerland, covering basic training, practical training, professional skills, and personal skills. In terms of basic training, recognized diploma programs are offered by the Swiss Federal Institutes of Technology in Zurich and Lausanne, and universities of applied science, etc. A professional surveyor should have at least two years of practical training. Professional skills are verified by passing the state examination, which covers four subjects, namely cadastral surveying, geomatics, land management, and business management. Specifically, the contents of the subjects include organization and procedures of cadastral surveying, land register, surveying and geo-information legislation, geodata collection, updating and management, land management, real estate and property valuation, property and land law, etc.

China has a multi-level education system for land management and cadastral survey, including higher education, vocational education and adult education (Cadastral-Template 2003). In terms of higher education, several universities offer bachelor's and master's programs for land resource administration, surveying and mapping, and geographic information system (GIS), such as Wuhan University, China University of Geosciences, Beijing Normal University, etc. Besides, vocational schools have land survey and mapping courses for training technicians for cadastre. Both universities and vocational schools offer short-term training (Cadastral-Template, 2003). Surveyors who pass a professional national exam and have at least two years of practical experience will be certificated as "registered surveyors" from the year 2007 in China. The annual surveyor exam 
covers three subjects, namely surveying abilities, surveying management laws and regulations, and survey case analysis. The subject surveying abilities requires a comprehensive surveying and mapping knowledge and methods, like geodesy, engineering survey, photogrammetry, remote sensing, GIS, cadastral mapping, real estate mapping, marine mapping, etc.

\section{Discussion and conclusion}

China's unique historical, economic, political and cultural background plays a significant role in shaping its cadastral system (Lin et al., 2015). The establishment and development of the Chinese cadastre is closely related to the development of the land system. The Chinese cadastre doesn't act as an essential tool for supporting land market, compared with the typical cadastral evolutionary path, due to historic and economic reasons, like an insufficiently developed land market. Furthermore, from historic perspective, we can draw the conclusion that the establishment of a well developed, organized and mature cadastral system needs a long stable social and economic environment.

The Chinese cadastral system is playing an increasingly important role in land administration. The continuous technique advances nowadays definitely accelerate the automation process of cadastral work, improve management efficiency, and make cadastral data more easily available. Apart from this, a multipurpose cadastral system is exerting its advantages, with the outcome of cadastral work applied in many other fields such as disaster management, urban planning, etc. (Lin et al., 2015), although still being limited to the governmental administration domain. The unified ideology and centralized political structure facilitate the establishment of a national standard and data model, and lower the implementation cost.

However, due to public's weak awareness of the cadastre, lack of financial support and professionals especially in rural areas, the maturation and full application of the Chinese cadastral system still have a long way to go (Yang and He, 2004). Thus, it's necessary to note that the cadastral issues that China is faced up with probably are the ones which have been resolved by those more developed countries. The ability to learn from and gain an understanding of expertise and capacity building experiences from these more developed countries will accelerate the maturation process of the cadastral system (Rajabifard et al., 2007).

To sum up, this paper reviews the Chinese cadastre in a comprehensive way, understanding its evolution from a historic perspective and the contemporary cadastre from various aspects, trying to further the existing studies on the Chinese cadastre. This paper is valuable for the limited research currently available on the Chinese cadastral system. Future studies include the Chinese 3D cadastre, how information revolution will affect the development of the cadastral system, and how land laws and regulations should improve to adapt to the rapid development of the Chinese economy.

\section{References}

Cadastral-Template, 2003. Cadastral template 2.0. http://cadastraltemplate.org/, accessed in Nov. 2020.
Cheng, J., Turkstra, J., Peng, M., Du, N. and Ho, P., 2006. Urban land administration and planning in china: Opportunities and constraints of spatial data models. Land Use Policy 23(4), pp. 604-616.

Fan, Z., 2007. Chinese cadastre 5000 years. China Land 2, pp. 44-46.

Feng, X., 2012. Research on cadastral management system in china - based on land resources optimal use. Master's thesis, Fujian Normal University.

Feng, X. and Sun, Y., 2011. The sustainable development of plain lakes in arid region - a case study of aiding lake. Arid Land Resource Environment 25(1), pp. 195-200.

Jiang, W., 2008. Build the roadmap - chinese cadastral development for 30 years. China Land 12, pp. 37-40.

Lin, Q., Kalantari, M., Rajabifard, A. and Li, J., 2015. A path dependence perspective on the chinese cadastral system. Land Use Policy 45, pp. 8-17.

Lin, Z., Tan, J., Zhan, C. and Qu, W., 2006. Cadastre. Science Press, Beijing.

Liu, L., 2010. The evolution of the land administration practice of nanjing national government. Master's thesis, Shan Dong University.

Liu, Y., 2019. Application of lidar scanning technology in 1:500 cadastral surveying and mapping. Beijing Surveying and Mapping 33(9), pp. 1102-1105.

Luo, X., 2009. Research on cadastral administration in china - taking zhoushan for example. Master's thesis, Shanghai Jiao Tong University.

Rajabifard, A., Williamson, I., Steudler, D., Binns, A. and King, M., 2007. Assessing the worldwide comparison of cadastral systems. Land Use Policy 24(1), pp. 275-288.

Shen, Z. and Cao, X., 1993. Cadastre and cadastral management in china. Surveying World 1(5), pp. 30-31.

Song, H., 2019. Application of oblique photogrammetry in large-scale mapping. Geological mining surveying and mapping 2, pp. 90-91.

Ting, L. and Williamson, I. P., 1999. Cadastral trends: A synthesis. Australian Surveyor 44(1), pp. 46-54.

Wang, S., 2001. Construction of the cadastral system with chinese characteristics. Resource 1, pp. 11-16.

Yang, L. and He, A., 2004. Cadastral management status in hunan, china. China Land 21, pp. 64-68.

Yearbook, C. S., 2017. National bureau of statistics of china, 2018. URL: http://www. stats. gov. cn/english/Statisticaldata/AnnualData.

Yu, J., 2003. Analysis and enlightenment from ancient chinese cadastral management. Journal of Huazhong Agricultural University (Social Science Edition) 47, pp. 87-89. 